Connotas. Revista de crítica y teoría literarias 
CONNOTAS. REVISTA DE CRÍTICA Y TEORÍA LITERARIAS. Enero - diciembre 2013, es una publicación anual editada por la Universidad de Sonora, a través de la División de Humanidades y Bellas Artes, en el Departamento de Letras y Lingüística. Blvd. Luis Encinas y Blvd. Rosales s/n, Col. Centro, C.P. 83000, Hermosillo Sonora; Tel. (662) 2592 136, (662) 2592 157, <www.uson.mx>, <http://www.connotas.uson.mx, connotas@capomo.uson.mx>. Editor responsable: Rosario Fortino Corral Rodríguez. Reservas de Derechos al Uso Exclusivo núm. 04-2006-020714184900-102. ISSN: 18706630; ambos otorgados por el Instituto Nacional del Derecho de Autor. Licitud de Título núm. 13434 y de Contenido núm. 11007, otorgados por la Comisión Calificadora de Publicaciones y Revistas Ilustradas de la Secretaría de Gobernación. Este libro se publicó con el apoyo del Programa Integral de Fortalecimiento Institucional C/PIFI 2013-12934

Se autoriza la reproducción total o parcial de los contenidos de la presente publicación, siempre y cuando se acredite adecuadamente el origen de los mismos.

Datos de contacto para la publicación: División de Humanidades y Bellas Artes, Departamento de Letras y Lingüística; Apartado Postal 793, Col. Centro, C.P. 83000, Hermosillo, Sonora, México. Tels.: (662) 259-21-87, Tel-fax 212-55-29. Correo electrónico: connotas@capomo.uson.mx Página web: http://www.connotas.uson.mx 


\section{Connotas. Revista de crítica y teoría literarias}

Núm. 13, año 2013

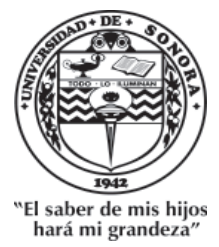


UNIVERSIDAD DE SONORA

RECTOR

Heriberto Grijalva Monteverde

VICERRECTORA

Arminda Guadalupe García de León Peñúñuri

Secretario General Académico

Enrique Fernando Velázquez Contreras

División de Humanidades y Bellas Artes

María Rita Plancarte Martínez

Departamento de Letras y LingÜística

Ana Bertha de la Vara Estrada

César Avilés Icedo

Rosa María Burrola Encinas

Fortino Corral Rodríguez

Leticia Martínez Figueroa

Jesús Abad Navarro Gálvez

Gabriel Osuna Osuna

María Rita Plancarte Martínez

DiRECTOR

Fortino Corral Rodríguez

Giuseppe Bellini

Consejo InTERnacional

Universidad de Milán

Carlos Pacheco

Luis Beltrán Almería

Universidad Simón Bolivar

Universidad de Zaragoza

Rafael Olea Franco

Helena Beristáin

El Colegio de México

Joan Oleza Simó

Universidad Nacional Autónoma de México

Universidad de Valencia

Raúl Bueno-Chávez

Dartmouth College

Julio Ortega

Evodio Escalante

Brown University

Luz Aurora Pimentel

Universidad Autónoma Metropolitana

Universidad Nacional Autónoma de México

Beatriz González-Stephan

Susana Reisz

Rice University

Aníbal González

The City University of New York.

José Carlos Rovira

Universidad de Alicante

Yale University

Aurelio González Pérez

Charles Tatum

El Colegio de México

Yvette Jiménez de Báez

The University of Arizona

Jorge Urrutia

El Colegio de México

Universidad Carlos III de Madrid

Nelson Osorio Tejeda

Universidad de Santiago de Chile

Emil Volek

Arizona State University 


\section{Índice}

\section{Artículos}

Una hermenéutica analógica para la literatura

Mauricio Beuchot Puente

La obra de Jorge Luis Borges durante la década de 1930: estudio de algunos elementos para la conformación de su poética en Discusión (1932)

Daniel Zavala Medina

Metáforas de la locura y la muerte en "Río subterráneo" de Inés Arredondo

Gabriel Osuna Osuna

La alteridad como vector de la construcción del yo: La muerte me da de Cristina Rivera Garza y El Gran Vidrio de Mario Bellatin Véronique Pitois Pallares

Uno soñaba que era rey de Enrique Serna: un espacio de contradicción Claudia Gidi

Una angustia compartida. Análisis de la voz narrativa en Mi hermano Carlos de Jorge López Páez

Jorge Antonio Muñoz Figueroa

De Los perros románticos y otros poemas de Roberto Bolaño Marina Martínez Andrade 
Las novelas del Crack, multiplicidad y superposición de mundos Ramón Alvarado Ruiz

La construcción del “otro" en la Relación de la jornada de Cíbola de Pedro Castañeda de Nájera

Guillermo Martínez Sotelo

Destino e historia en Margarita, está linda la mar de Sergio Ramírez

María Rita Plancarte Martínez

\section{Notas}

Identidad negada y mundo al revés en Santa María del Circo de David Toscana

César Avilés Icedo y María Elena González Borgaro 203

"El buen ejemplo" de Vicente Riva Palacio: la historia de un cuento

Marco Antonio Chavarín González

Organización descriptiva en Catarina de San Juan, princesa de la India y visionaria de Puebla

Silvia Guadalupe Alarcón Sánchez

Genealogías en Todo aqui es polvo de Esther Seligson. Lectura a partir de los epígrafes

Luz Elena Zamudio Rodríguez

\section{Reseñas}

Martha Elena Munguía Zatarain. La risa en la literatura mexicana (apuntes de poética)

Silvia Alicia Manzanilla Sosa 
Véronique Pitois-Pallares. El arte del fragmento: El Gran Vidrio de Mario Bellatin

Julio César Zárate Ramírez 255

Nicolás Kanellos. Hispanic Immigrant Literature: El sueño del retorno Josué Gutiérrez González

Dante Salgado. Brevísima relación de la idea de amor en Occidente Diana Vanessa Geraldo Camacho 271

Mara L. García. Paco Yunque: una mirada crítica Juan Paredes Carbonell 279

Abstracts 283

Résumés

Normas editoriales 



\title{
Uno soñaba que era rey de Enrique Serna: un espacio de contradicción
}

\author{
Claudia Gidi*
}

Resumen:

Uno soñaba que era rey, de Enrique Serna, se inscribe en la tradición de la novela urbana y recrea la Ciudad de México como espacio de horror y deshumanización, dando cauce y expresión a las voces sociales que pueblan la metrópoli. De este panorama surgen dos universos particularmente trabajados en los que se desarrolla la acción novelesca: el lumpen y el de las clases adineradas; dos mundos antitéticos que se entrecruzan y afectan mutuamente. Sin embargo, lo verdaderamente significativo es que ambos universos funcionan como espejo deforme del otro y están configurados con rasgos que los identifican e igualan. Son los rostros de una misma deformidad, las dos caras de la miseria humana.

Palabras clave:

Novela urbana, voces sociales, grotesco, sarcasmo, parodia.

Los rostros que ofrece la literatura mexicana contemporánea son tan variados y complejos que resulta difícil trazar un perfil más o menos justo del acontecer literario; la tarea se complica más con la cercanía temporal, que con frecuencia obnubila el juicio crítico. ¿Cuántas de las obras actuales que pueblan las vitrinas de las librerías resistirán el

\footnotetext{
* Universidad Veracruzana.
} 
paso del tiempo? ¿Cuántas de las que han merecido elogios y que han sido saludadas como "acontecimiento editorial" merecerán una segunda edición? Y sin embargo, estas prevenciones no nos eximen de la responsabilidad de leer con atención lo que se ha producido en las últimas décadas en nuestro país y de ir formando juicios críticos que, sin duda, el tiempo matizará.

Una de las tendencias más claras de la narrativa mexicana actual es la delectación en fabular mundos siniestros, habitados por personajes monstruosos, teñidos por el acento del desencanto. $Y$ tal vez esto no sea extraño, tratándose de un país herido por la violencia, por la desigualdad y la corrupción. En este ensayo voy ocuparme de Uno soñaba que era rey (1989) de Enrique Serna. Y si me detengo en esta novela es porque en ella encontramos una expresión nítida de dicha tendencia. Me parece también que no ha sido suficientemente estudiada por la crítica. Voy a tener en cuenta dos aspectos que resultan fundamentales para ubicar su propuesta estética: en primer lugar, su composición basada en un juego de voces y acentos que se entrecruzan ${ }^{1}$-el propio Serna la considera una obra coral en la que confluyen lenguajes y puntos de vista contradictorios (véase entrevista con Jeannet)-, y en segundo, el juego metafórico de los espejos que instaura la obra, así en su nivel temático, como en lo que se refiere a su estructura. Ambos elementos me parecen centrales para la comprensión el texto.

\section{Voces y acentos en la novela}

Mediante la recreación de voces se explicita en la novela un referente histórico concreto, una realidad reconocible para el lector. Pero muy aparte de la elección de dicho referente, me parece fundamental identificar la estética desde donde se reelabora y se le da vida. Si bien el

${ }^{1}$ La enunciación de las voces es, desde luego, un problema fundamental para la comprensión del género novelesco en cuanto tal. Véase Voloshinov, Valentin N. El 
texto parece conectarse con el flujo de la vieja tradición del realismo, es preciso reconocerle la deliberada reacentuación de esa estética, lo que puede apreciarse en el esmero con que se matiza el lenguaje, oscilante entre la procacidad bebida en el contexto social y la constante estilización metafórica, ubicada en los linderos de lo onírico y el delirio de la droga.

Elisabeth Pagnoux afirma que la ciudad se convirtió en las últimas décadas en "una figura central de la creación mexicana" (32); al punto que "la narrativa defeña ha sustituido a la novela de la Revolución, pasando a ser sinónimo de novela a secas" (32). Frente a una ciudad en vertiginosa transformación, los escritores asumen diversas posturas éticas y estéticas, creando obras que ensanchan la tradición literaria. Uno soñaba que era rey se inscribe en el género de lo urbano; continúa la veta abierta por La región más transparente, dialoga con otros textos contemporáneos y propone su propia recreación del monstruo que es la ciudad de México. Es un texto artístico que busca dar cauce y expresión a la multiplicidad de voces sociales que pueblan la metrópoli contemporánea.

Si durante la segunda mitad del siglo XX, la ciudad se convirtió en una trágica síntesis del país -riqueza y pobreza extremas, cultura y analfabetismo, modernidad y supervivencia de formas ancestrales de vida-, por su parte, la narrativa de la ciudad de México ha multiplicado los espacios, los tiempos, los personajes y sus hablas. Sin embargo, esta misma diversidad se ha manifestado como fuente de conflicto y como fragmentación. La integración de innovaciones lingüísticas a la novela urbana cobra sentido en la medida en que un habla se confronta con otras. La monstruosidad y la deshumanización del Distrito Federal se manifiesta "en la ausencia de comunicación, en la multiplicación de las fronteras, en la afirmación de la equivalencia entre lo múltiple y lo caótico” (Pagnoux 38). Por lo que el protago-

marxismo y la filosofía del lenguaje, Alianza, Madrid, 1992. Lo es de manera particular en esta novela, merced al rico trabajo de recreación de tonos y acentos. 
nista de esta literatura se topa de frente con un mundo doloroso, de incomprensión, que lo apresa.

Dentro del amplio repertorio de la novela urbana contemporánea, en la que se ensayan diversas maneras de recrear la ciudad, destaca la narrativa comprometida directa y claramente con los problemas sociales. Zubiaurre-Wagner considera que en ella

la ciudad recupera nuevamente su inicial peso y realidad física. En este caso, la deuda con la tradición realista se manifiesta con toda nitidez: se reinstauran en novelas del estilo de La ciudady los perros de Mario Vargas Llosa las fidedignas narraciones de espacios "reales", así como la denuncia, tan enquistada en la narrativa decimonónica, de la pobreza y la sordidez de ciertos ámbitos urbanos. Esta tradición realista y denunciatoria se prolonga, en nuestros días, aunque con notables variantes temáticas y estilísticas. (324-325)

Uno soñaba que era rey tiene vínculos con este tipo de novela urbana: comparte con ella la preocupación por la causa social, la vocación de denuncia de las injusticias y el interés por recrear espacios "reales", es decir, reconocibles y familiares para el lector.

Entre los rasgos que caracterizan a la novela mexicana de los años ochenta puede destacarse que en ella la ciudad cumple una función axial, como espacio del horror y la degradación y que muestra una actitud de absoluto desencanto frente a las instituciones oficiales. Se trata de una narrativa que vuelve al realismo, aunque incorporando los aprendizajes formales de otros años, para llevar a cabo un retrato crítico de la sociedad. Frecuentemente en ella se echa mano, como huella de su tiempo, de los códigos del periodismo y los medios informativos, en tanto recurso expresivo para elaborar sus preocupaciones fundamentales: la vida cotidiana y la violencia (Sefchovich 223-225). Todos estos rasgos aparecen recreados en la novela de Serna que ahora nos ocupa.

La acción en Uno soñaba que era rey transcurre de abril a septiembre de 1984, en la Ciudad de México. Y si parto de que la novela recrea artísticamente una realidad específica, sus condiciones 
socioculturales y las voces sociales que la conforman, creo que bien vale la pena recordar lo que ocurría en nuestro país en los años ochenta: la economía mexicana había llegado a una crisis sin precedentes en la historia moderna. En consecuencia, el régimen ancestral de desigualdades sociales se agravó considerablemente; el nulo crecimiento económico llevó al país a un empobrecimiento general y a una concentración cada vez mayor de los recursos y la riqueza en manos de cada vez menos mexicanos. En las grandes ciudades se incrementaron los índices de delincuencia, aumentando de forma alarmante la delincuencia juvenil (Aguilar Camín y Lorenzo Meyer).

Por lo demás, y volviendo a la obra de Serna, me parece significativo que el autor haya elegido precisamente el año de 1984 para datar la acción de su obra. Al recrear la vida urbana en ese año, se inserta en el marco de la primera gran crisis económica de la historia moderna de México, pero justo antes del sismo de 1985, cuando surge la llamada sociedad civil, de la que se esperaba partiera la transformación del país, no sólo de su rostro, sino de sus estructuras.

De este panorama surgen los dos universos particularmente trabajados por Enrique Serna, en los que se desarrolla la acción novelesca: el lumpen, encarnado en el Tunas, niño "chemo" de doce años, y el de las clases adineradas, donde encontramos a su contraparte, Marquitos Valladares. Estos dos mundos se entrecruzan, se afectan y se determinan mutuamente a lo largo de la novela. Podría decirse que cada uno de ellos funciona como espejo deformante del otro. ${ }^{2}$

\section{Juego metafórico de espejos}

La existencia de dos mundos contrastantes se advierte desde el principio de la obra. Y conforme avanza la narración los contrastes se

${ }^{2}$ La distribución de los capítulos de la obra apunta también a una estructura binaria: de los dieciséis capítulos que la conforman, ocho están centrados 
van haciendo cada vez más intensos y complejos. Una distinción significativa en la representación artística que hace Serna es la clara separación de dichas realidades distanciadas geográfica, cultural, económica e ideológicamente. Sin embargo, y esto es fundamental, al mismo tiempo ambos grupos están configurados con rasgos equivalentes que los identifican e igualan. En los dos mundos hay un joven de doce años que cometerá un asesinato. Los dos jóvenes "heredarán" las características de su entorno familiar y social: llevan el nombre de sus padres e imitan sus pautas de conducta. Además, ambos grupos se caracterizan por carecer de un vínculo cercano y amoroso entre padres e hijos. Este asunto es tan significativo que abarca las relaciones entre los jóvenes y sus padres, y entre estos últimos y sus propios padres. Puede hablarse, por lo tanto, de una fractura invisible en las relaciones parentales o, más aún, de la ausencia de las figuras paterna o materna, en un sentido profundo. Sin duda, Serna aprovecha en su novela un fenómeno frecuente en México, particularmente en las clases populares: la ausencia del padre en el núcleo familiar.

He dicho que los dos grupos sociales que pueblan el universo ficcional funcionan entre sí como espejos confrontados. Quisiera agregar ahora que el espejo mismo ha sido tematizado dentro de la novela: por un lado, en la obsesión de Valladares y su hijo por admirar su imagen reflejada, como un Narciso; y por el otro, en el Tunas al sentirse reflejado en la figura de los "ajolotes" que nadan en un charco citadino de aguas sucias. Marquitos Valladares, al igual que su padre, siente una debilidad narcisista e irresistible por su cuerpo repetido en los espejos. La voz narradora dice: "Dos espejos contrapuestos multiplicaban su imagen hasta el infinito. Miró con delectación su cuerpo esmirriado y blanco, la carita de príncipe, los brazos de venas azules, la pinga escondida y anciana. Todo él le gustaba. Qué bien le caería una chaquetita" (172). De Marcos Valladares padre, el narrador recrea varias situaciones equivalentes:

básicamente en el mundo de las opulentas clases adineradas, mientras que los ocho restantes lo están en el universo del Tunas. 
Mientras esperaba en el ascensor tuvo la comezón de mirarse al espejo. Había hecho jogging esa mañana, sentía la sangre ligera, los músculos firmes, y quería saber si la placidez interior se reflejaba en su rostro. Pero no cometería la indiscreción de mirarse ahí. De todos los espejos con los que sostenía un diálogo erótico, éste era el que más lo incomodaba, por ser un espejo público, democrático, abierto a la vanidad de todo el personal. $(48-49)$

La fascinación que ambos personajes sienten por la propia imagen pareciera apuntar a la incapacidad de los miembros de su grupo social de ver al otro, de tan encantados que se encuentran consigo mismos.

Al Tunas, en cambio, el narrador le cede la voz para hablar con unos "ajolotes" que se hallan en un "charco de aguas verdinegras" (102). En este soliloquio percibimos que el niño se enfrenta consigo mismo, al identificarse con esos pequeños seres acuáticos. Sólo que el panorama que le devuelve esa suerte de espejo es desolado y triste:

La neta les tengo envidia, mugrosos ajolotes. Ahí en el charco nadie los molesta, no hay tira ni ley, ha de ser chido rolarla como ustedes, nadar en agua tibiecita y cochina, qué agasajo, sin que nadie los venga a jalar de las patas y les suelte acá un rollo sobre los delitos contra la salud y ustedes se tengan que callar aunque no sepan qué chingados es eso. (102)

Antes de explorar los significados que evoca la presencia del ajolote, es necesario mencionar que hay un equívoco muy común en México, sobre todo en la meseta central, que consiste en llamar ajolote al renacuajo o larva de la rana. En este caso es evidente que el Tunas se equivoca y llama ajolotes a los renacuajos; sin embargo, lo dicho tanto por el narrador como por el muchacho nos remite a la fuerte carga simbólica de que es portador el ajolote.

Se trata de un anfibio endémico del Valle de México que tiene la capacidad de reproducirse precisamente en estado larvario, primitivo; es decir, es capaz de reproducirse antes de llegar a adulto, conser- 
vando sus caracteres juveniles. Más importante aún es que el ajolote está ligado a varios mitos mexicanos. Su nombre náhuatl, axolotl, en una de sus acepciones quiere decir "monstruo de agua", y representa la advocación acuática del dios Xólotl, hermano mellizo de Quetazcóatl, el "gemelo precioso".

La dualidad Xólotl, monstruoso, y Quetzalcóatl, hermoso, se puede rastrear en la novela en la pareja que forman el Tunas y Marquitos. Por su aspecto físico no dudaríamos en identificar a Marquitos como el ser hermoso: blanco, "la carita de príncipe", los "cabellos de paje inglés... la nariz maliciosamente respingada y los pómulos salpicados de pecas"; mientras que el Tunas, con su "cabeza de cabellos cortos y tiesos", no podría ser sino el monstruoso. Sin embargo, esta caracterización es superficial y aparente. Ambos son gemelos monstruosos, a un tiempo iguales y diferentes.

Los dos niños han heredado, aparte del nombre de sus padres, sus filias y fobias, los juegos de exclusión social con los que se identifican los miembros de un grupo y se segrega a los diferentes, adjudicándole al otro los rasgos negativos, no aceptados por una comunidad. Además, como en un espejo que invirtiera las imágenes que refleja, tal como lo hace el ojo humano o la cámara fotográfica, la sexualidad está asociada, en el mundo del Tunas, a una figura femenina, Carmen -la madre del Tunas-, así como a la culpa y el pecado; mientras que en el mundo de Marquitos se asocia con el poder y el cinismo, en la figura de Marcos Valladares. Para Carmen la sexualidad implica una lucha constante contra el pecado; mientras que, para Valladares, simboliza la ostentación del poder patriarcal, asociada a la vanidad y superficialidad.

De este modo he llegado a hacer una abstracción para observar en esta especie de "espejo invertido" que en el mundo de las clases bajas hay un padre ausente y una madre tan dañada que se ha vuelto un gruñido; mientras que en el de las clases adineradas es la madre una figura casi ausente de tan difusa y el padre es un ser vanidoso y autoritario. En cuanto a la sexualidad, el grupo social de Marquitos está representado por un varón que detenta el poder; mientras que el del Tunas lo está por una mujer que vive sumisa y atormentada por la culpa. Se puede decir, pues, que ambos grupos son la representa- 
ción simbólica de los sexos y de la relación desigual, sexista y patriarcal, que los une. Finalmente, insisto, estos dos mundos son las caras de una misma moneda, de una misma deformidad. Deformidad que permite recrear la imagen artística de la Ciudad de México como dos rostros opuestos, en tanto que pertenecen a mundos diversos, pero iguales, en cuanto que recrean lo deplorable de una misma miseria humana.

\section{Composición narrativa}

Veamos ahora cómo la voz narradora articula estos universos y qué tipo de relaciones establece con los personajes del universo ficcional. Desde mi punto de vista, esta voz no pertenece a ninguno de los dos mundos arriba referidos, aunque es posible advertir su contemporaneidad con los sucesos narrados, ya que estos sucesos le tocan tan de cerca que no le es dado mantener una distancia afectiva con los personajes. No obstante, quizá su rasgo más significativo sea que se trata de una voz que domina a las de sus personajes, imponiéndoles su horizonte perceptual y valorativo; es decir, que orienta ideológicamente el relato. El narrador se encuentra por encima de las voces de los personajes: siempre sabe más que ellos y se constituye a sí mismo como autoridad. Al mismo tiempo, se atribuye la capacidad de ingresar, sin límites, a la subjetividad de sus personajes. En este sentido la vOz narradora funciona como una especie de doble del yo autoral, pues es posible escuchar cómo detrás de las enunciaciones del narrador resuena la potente voz del autor que sentencia autoritario sobre el universo novelado.

Sin embargo, es preciso reconocer que hay un trabajo estilístico de hibridación de voces. El discurso del narrador frecuentemente es tocado, orientado y matizado por la introducción en su interior de las voces de los personajes. De tal modo que la palabra del narrador no siempre es unívoca, sino sinuosa, aunque al final termine por imponer su tono y su valoración.

En términos generales puede decirse que la voz narradora tiene una fuerte propensión por la construcción de imágenes grotescas y 
efectistas, así como por la ironía y el sarcasmo. Sin embargo, es en el mundo del Tunas donde las imágenes grotescas proliferan, mientras que en el de Marquitos, la ironía y el sarcasmo son los ingredientes más frecuentes en las enunciaciones valorativas del narrador.

En la presentación de Damián, padrastro del Tunas, como en la de todos los personajes significativos del mundo marginal, las características físicas recreadas por el narrador son siempre grotescas: "Cincuentón avejentado, arrastra consigo un resentimiento contra la vida mucho más visible que su enorme panza" [...] "Es un emisario del aburrimiento y del orden" (13). Y aquí vale la pena destacar que, además de lo grotesco de la imagen, nos encontramos frente a una valoración del personaje. Antes de que tengamos la oportunidad de verlo actuar, escuchar su voz o lo que otras voces opinan de él, el narrador ha emitido ya su juicio: se trata de un personaje que además de tener un aspecto desagradable es un resentido.

Dos páginas adelante, el narrador construirá, dentro de la conciencia alucinada del Tunas, una imagen aún más grotesca de la apariencia de Damián:

La cara del tío postizo se hincha y adquiere proporciones monstruosas. Es una cara color de hiedra, limitada al norte por unos párpados náufragos de sus cuencas y al sur por una verruga incrustada en el mentón. A oriente y poniente la cierran dos patillas cenicientas que apuntan hacia una nariz aplastada, con anchas fosas nasales repletas de cerdas negras que invaden las comisuras de una boca sin labios. (15. Las cursivas son mías)

La imagen que surge de esta detallada descripción expresa todo el rechazo que siente el narrador por el personaje (en perfecta coincidencia con la valoración del mismo Tunas respecto de Damián).

En cambio, el tipo de imágenes que construye en el mundo privilegiado se encuentra marcada por el sarcasmo y la ironía. En el capítulo III, el narrador presenta a Marcos Valladares y no lo hace a partir de su aspecto físico, ni aparece ningún rasgo grotesco. Por el contrario, comienza con una narración analéptica en la que se cuenta la juventud de Valladares. Este recurso narrativo es de lo más eficaz ya 
que resalta los contrastes entre ambos mundos, y subraya de nuevo los distintos tipos de relación que el narrador establece con ellos. En el caso referido empieza, concretamente, hablando de los estudios de Valladares en el "Instituto Patria" (40). Llama la atención el nombre del colegio ya que resulta contradictorio pues hace pensar en el carácter patriótico de la institución, cuando lo que en realidad ocurre es que se forman en él los personajes de la clase alta, cuya máxima aspiración es el estilo de vida estadounidense. Como se advierte, la ridiculización que el narrador hace del grupo al que pertenece Valladares no se vincula tanto con lo grotesco, sino con la ironía y el sarcasmo:

Amigo de millonarios, infalible ligador de gringas en Acapulco, asistente al Jockey Club con trajes prestados, diestro motociclista en el circuito avenida Insurgentes-Paseo del Pedregal, novio de Paty Torres Landa, Georgina Braniff y otras niñas retratadas en las páginas de sociales, Marcos se consideraba beneficiado por un proceso de selección darwiniana. (42-43)

La voz narradora subraya siempre la distancia ideológica que lo separa del personaje y de alguna manera del mundo que representa. Construye al joven Valladares haciendo énfasis en su falsedad, su afán de pertenencia a la clase alta, y su habilidad de trepador que le asegura una vida de rico. Todos estos rasgos se intensifican con la afirmación que, desde la perspectiva de Valladares, hace el narrador, al considerarse a sí mismo "beneficiado por un proceso de selección darwiniana".

Por otro lado, me parece que existe una preocupación del narrador por explicarle al lector de dónde vienen las características de los personajes: se ocupa de su infancia, de las relaciones con los padres. Pareciera que, desde su perspectiva ideológica, el periodo de formación de la infancia marca, de manera definitiva, la existencia de los seres humanos. No obstante lo cual, dicha preocupación se manifiesta usualmente cargada de una fuerte dosis de ironía y humor.

Un aspecto que me gustaría destacar ahora es la relación que establece el narrador con los niños de ambos universos. El grado de cercanía afectiva que hay entre él y los niños resulta por completo 
contrastante y revela su posición ética: el Tunas aparece en el primer capítulo, lo cual habla ya de la preeminencia que el narrador le otorga como personaje y de la importancia capital que tendrá en la composición total de la narración. El recurso artístico de colocarse a su lado, de ubicarse en la misma perspectiva espaciotemporal que el Tunas, es un primer indicio de la cercanía afectiva y la simpatía que siente por el muchacho:

si Jorge Osuna, alias el Tunas, está aquí, en este dolor heraldo de la sobredosis, tendría que levantarse a tomar un poco de oxígeno. [...] Porque Jorge Osuna, si está de verdad aquí-no está solo. (9. Las cursivas son mías)

Para la voz narradora, el Tunas no es fácilmente aprehensible: "Es difícil verlo por dentro, porque repele a los intrusos que invaden su soledad" (8); hay que acercarse a él lentamente, con tiento y respeto: "El cazador de sus secretos debe andar a tientas para no engañarse con ideas preconcebidas, debe odiarlo y quererlo, hacer conjeturas desesperadas y toparse al final del camino con la misma cerrazón que al principio" (8). El narrador construye al Tunas poco a poco: su cara, sus manos, sus pulmones, su dolor "heraldo de la sobredosis" (9), sus cabellos "cortos y tiesos" (10). Nos aproxima paso a paso al personaje, hasta sentirlo cerca.

Por contraste, Marquitos no aparece hasta el final del tercer capítulo. El narrador lo muestra jugando tranquilamente "a derribar aviones japoneses que sobrevolaban la pantalla de su Nintendo" (64), después de haber martirizado al viejo jardinero de su casa amagándolo con una de las pistolas que colecciona su padre. La voz narradora no se contenta con subrayar los grados de prepotencia que caracterizan la relación de Marquitos con sus semejantes, sino que incluso lo ridiculiza, se burla abiertamente de él al marcar un defecto de pronunciación: emite todos los sonidos de "s" como si fueran " $z$ ", a la española, clásica forma de los niños mimados que tienen atrofiada el habla.

Además, comparado con Marquitos, el Tunas resulta ser un personaje mucho más elaborado. Son claros sus múltiples rasgos negativos pero en ciertos momentos el narrador muestra al muchacho ha- 
ciendo énfasis en su indefensión; habla del niño asustado que pervive bajo el chavo banda capaz de "achicalarse" a cualquiera. ${ }^{3}$ En su primera alucinación, tras imaginar a su padre, el pensamiento del Tunas se incorpora a la voz narradora:

perdóname, jefa, mi papá se me apareció solito, te juro que yo no le hablé, vino a verme con su vieja, me quiere asustar para que le haga compañía en el Metro, digo en el cielo, digo en la pipa. (17. Las cursivas son mías)

De este fragmento importa señalar la confusión del personaje y su miedo. Incluso por la vía negativa, por la rabia y la injuria, el narrador deja ver en el fondo al niño vulnerable, así como su actitud compasiva frente a la situación del muchacho. En el capítulo V, "El Tunas quiere un globo", dice:

El Tunas pierde altos preciosos envidiando a los niños que señalan el globo de su preferencia: yo quiero el del gato, mami, cómpramelo, no ése no, el más grandote; niños a los que desearía madrear con el bóxer que lleva en el bolsillo, achicalar a cadenazos o por lo menos ahogar en la cubeta de aguas negras donde se reflejan los cables de alto voltaje que taladran las palmeras de Fray Servando. (163. Las cursivas son mías)

$\mathrm{Al}$ incorporar a su propio discurso las voces de los niños que pueden expresar libremente su caprichoso deseo, el narrador acentúa el abismo que separa a estos de la mísera condición del Tunas. Por si fuera poco, pone una y otra vez de relieve la pobreza del paisaje reflejado en la cubeta del muchacho. Unas líneas adelante el ren-

${ }^{3}$ Frédéric-Yves Jeannet en su entrevista a Enrique Serna afirma que: “En casi todos los casos, tus personajes rechazan, por así decirlo, la posibilidad de que el lector se identifique con ellos. Por el sarcasmo con el que los manejas y describes, y porque ninguno de ellos es un ejemplo de rectitud. En Uno soñaba que era rey, ¿con quién te identificas?” La respuesta del escritor es clara: “Con el Tunas” (153). 
cor y el resentimiento del Tunas, así como el énfasis de la voz narradora, llegan al máximo:

Hay de globos a globos. El globo del Tunas es un grano de pus, una teta cancerosa, un rencor hueco, una lágrima de gas, un vientre hinchado de silencio y luto, es un antiglobo, mientras que los niños del cine Sonora quieren una burbuja cursi para ilusionarse con la posibilidad de volar. (163)

Me parece que en este último párrafo, el narrador aventura una metáfora: hay de vidas a vidas, pareciera decir; y su indignación llega al límite. Sin embargo, si bien hay diferencias palpables en el trato que le da a cada niño, a los dos protagonistas los construye con ciertos rasgos equivalentes. Como apuntaba líneas atrás, ambos niños cometen un asesinato, aunque las razones y las circunstancias son completamente diferentes. Marquitos decide dispararle a un "naco" para impresionar a su amigo Iván, con la confianza de que no importa demasiado ya que "Los nacoz no son gente" (183). El Tunas, en cambio, asesina a su padrastro después de ser víctima de la violencia que le infligieron la pareja de su madre y ella misma.

La parodia es otro de los recursos estilísticos más trabajados en la obra de Serna. Mediante la parodia -recurso que se caracteriza por mantener los rasgos estilísticos del discurso parodiado, para que el receptor lo reconozca, pero en el que opera una reorientación semántica de las intenciones originales, ya que se puebla de otros sentidos siempre desenmascaradores- el autor recrea una gran variedad de discursos, entre los que descuellan los que se transmiten a través de los medios masivos de comunicación. De esta manera caracteriza a los media como organismos corruptos, al servicio de las clases en el poder; como promotores de posturas reaccionarias, responsables de la creación y difusión de una imagen falsa de la "realidad". Además, es importante señalar que sus discursos permean el imaginario social orientando no sólo el comportamiento de los personajes y sus valoraciones de los sucesos, condicionan incluso sus fantasías.

Pareciera como si en la recreación de los tonos y las voces que difunden los medios masivos de comunicación, en la forma en que 
falsean la realidad, Serna retomara la propuesta de Baudrillard que identifica a los media como los promotores de la "no comunicación", si se entiende comunicación "como un intercambio, como el espacio recíproco de una palabra y una respuesta, por lo tanto de una responsabilidad [...] una correlación personal entre el uno y el otro en el intercambio" (202). ${ }^{4}$ Por lo tanto, aunque dentro de la fábula sea un programa de radio el que primero vincule, por decirlo de alguna manera, el mundo de Marquitos con el del Tunas, este "vínculo" no da lugar al diálogo, sino que fomenta una relación desequilibrada donde sólo un grupo tiene la palabra y el otro no tiene posibilidad de respuesta.

En el capítulo II de la novela se recrea una transmisión radiofónica en vivo en la que escuchamos de manera directa las voces de personajes pertenecientes, o cercanos, al mundo de Marquitos Valladares, los cortes publicitarios y la rúbrica de la estación. No se trata de la reproducción de un guión, sino de la recreación paródica de una transmisión en vivo, y por ello los diálogos de los personajes aparecen sin ninguna marca textual que identifique al responsable del discurso. A pesar de esto, la relación que se establece entre las voces mismas, orquestadas por el locutor, y el contenido de cada enunciación, da la posibilidad de que el lector reconozca, sin lugar a dudas, al personaje que habla en cada momento.

-El aspecto económico del premio es muy secundario. Ni con todo el oro del mundo podríamos recompensar al niño que comete un acto heroico. Lo que buscamos es darle una recompensa moral a él y a todo nuestro pueblo. Estamos seguros de que la nación entera lo acompañará con el pensamiento en su viaje a Roma y al verlo besar la mano de Karol Wojtyla cada mexicano dirá por dentro "aquí está

\footnotetext{
4 'Toda la arquitectura actual de los media se funda sobre esta última definición: son lo que veda para siempre la respuesta, lo que hace imposible todo proceso de intercambio (como no sea bajo formas de simulación de respuesta, estas mismas integradas al proceso de emisión, lo cual no cambia en nada la unilateralidad de la comunicación)" (Baudrillard 202).
} 
México", éste es el verdadero rostro de nuestro país, aquí está México, en la nobleza de este niño que no habría nacido si un anticonceptivo criminal lo hubiera matado apenas era un embrión, aquí está México, en su fe mariana. (35)

En este caso se trata, por supuesto, de un discurso conservador, cursi y deshumanizado, del que se desprende fácilmente la postura de su emisor -el "humanista" Homero Freeman- frente a temas morales, que repercuten, por ejemplo, en asuntos de salud pública: considera criminal el uso de anticonceptivos y da por sentado, sin la menor posibilidad de discrepancia, que México es (y está implícito que así debe ser) un país fiel al papa y a su fe mariana. Vemos así cómo en esta forma discursiva no mediada por el narrador se manifiestan algunos de los rasgos ideológicos que identifican y caracterizan a los personajes y su grupo social. ${ }^{5}$

Observemos ahora cómo los media aparecen en el universo del Tunas. En el primer capítulo de la novela, el niño tiene una alucinación, producto de la droga, con las piernas de Isela Vega, en la que los familiares de la vedette son actores a los que -dice la voz narradora- el Tunas "ha visto actuar en las películas de Tin Tan" (26). Los diálogos, el decorado y la situación misma son una recreación paródica de escenas del cine mexicano de la "época de oro", tan marcado por el melodrama. La manera como el Tunas imagina la vida familiar, y sus momentos significativos, es como la ha representado gran parte del cine nacional, aunque su propia realidad sea la antítesis de dicha imagen cinematográfica.

Con este último ejemplo se puede apreciar cómo el lenguaje de la imagen (del cine y la televisión) es un instrumento eficaz para proponer normas de comportamiento social y maneras de ver y enfrentar el mundo. "Si no genera santos y héroes -dice Carlos

5 “Ciertas formas dialógicas, sin mediación narrativa alguna, además de ser principio de acción pueden trazar perspectivas temporales, cognitivas e ideológicas que se derivan del propio diálogo sin que nadie las haga explícitas” (Pimentel 119). 
Monsiváis- el cine sí produce, y a raudales, símbolos con los cuales identificarse" (53).

En el capítulo XII, llamado "El simulacro", Ismael Rodríguez, padre del Gritos, otro niño del universo lumpen, debe representar y grabar una escena que le permitirá participar de manera fraudulenta en el concurso Quo melius Illac, premio instituido para reconocer a aquellos niños que hayan realizado una acción heroica. Esta escena trata del supuesto incendio de su casa, en el que su hijo Pedrito rescata de entre las llamas a su hermano menor. Lo primero que salta a la vista es que el nombre del personaje, padre del Gritos, es igual al del cineasta Ismael Rodríguez ${ }^{6}$-uno de los directores más importantes y representativos del cine mexicano de los años cuarenta-; ambos personajes, tanto el de referencia como el de Serna, cumplen una función similar: crear un tipo de ficción que responda a las expectativas del público; en el caso la novela, el de los jueces del concurso.

Como parte de los preparativos, el improvisado director da instrucciones al fotógrafo "con el tono autoritario de un consumado cineasta". "El chiste -explica el personaje- es que tome al niño en plena carrera, no le hace si la foto sale movida, lo que importa es el dramatismo, ¿me entiende?" (110). Del tratamiento que hace de esta escena la voz narradora sobresale el tono populachero y melodramático: "La abuela se detuvo para mirar atrás con los ojos húmedos, como si quisiera ver la casa por última vez". Poco después, la escena se sale de control y llega a un paroxismo grotesco cuando al "llanto del bebé" se suman los "gritos de pánico", el intercambio de "golpes, insultos y caricias obscenas"; el aceite hirviendo de un anafre que salta para caer en los ojos de un perro, y los "aullidos" y "ayes" en "horrísono estruendo" (117).

${ }^{6}$ Una de las películas más célebres de Ismael Rodríguez, quien convertiría en ídolo popular a Pedro Infante, es Nosotros los pobres. De esta película, estrenada en 1947, ha dicho el crítico Jorge Ayala Blanco: "Es un nefando producto populachero y todo lo contrario al mismo tiempo. Existe como una piedra de toque del cine mexicano, como un objeto maravillosamente monstruoso" (121). 
La presencia de los medios de comunicación en la novela de Serna es tan abundante que los ejemplos podrían ampliarse hasta el cansancio. Sin embargo, me parece que con lo arriba expuesto se puede apreciar que la recreación de sus discursos contribuye a la caracterización de los grupos sociales y sus voces; de la misma manera que funcionan como referente y modelo de conducta para los personajes. En resumen, los media constituyen un indicador importante para la configuración de las voces confrontadas en este universo. Generalmente en dichos discursos se hace intervenir los recursos de la ironía y la parodia. Sin embargo, no siempre ocurre así ya que en algunos momentos la crítica social es directa e incluso demasiado obvia, llena de lugares comunes.

Por último, conviene señalar que en esta novela el autor ha investigado las posibilidades de una narración sustentada en diversos formatos y géneros. Aprovechando, de manera lúdica, una amplia gama de modalidades expresivas, así como distintos modos de aprehensión de la realidad. Quisiera insistir también en la importancia capital de la dualidad Xólotl-Quetzacóatl que simboliza las dos caras de una misma moneda, de una misma deformidad, que en este caso configuran la representación artística de la Ciudad de México como rostros opuestos, en tanto pertenecientes a mundos diversos, pero iguales, en cuanto recrean lo deplorable de una misma miseria humana.

\section{Bibliografía}

Ayala Blanco, Jorge. La aventura del cine mexicano. México: Posada, 1985. Baudrillard, Jean. "Réquiem por los media". Crítica de la economía politica del signo. México: Siglo XXI, 1974.

Jeannet, Frédéric-Yves. "De puntos suspensivos y otras minucias. Entrevista con Enrique Serna". Tema y variaciones de literatura 6 (1995): 159-182.

Monsiváis, Carlos. Aires de familia. Cultura y sociedad en América Latina. Barcelona: Anagrama, 2000.

Pagnoux, Elisabeth. "La Ciudad de México o la emergencia de la voz urbana". Medio siglo de literatura latinoamericana 1945-1995, vol. 2. México: UAM, 1997. 
Pimentel, Luz Aurora. El relato en perspectiva. Estudio de teoria narrativa. México: Siglo XXI/UNAM, 1998.

Sefchovich, Sara. México: país de ideas, país de novelas. México: Grijalbo, 1987.

Serna, Enrique. Uno soñaba que era rey. México: Planeta, 2000.

Voloshinov, Valentin N. El marxismo y la filosofía del lenguaje. Versión española de Tatiana Bubnova. Madrid: Alianza Universidad, 1992.

Zubiaurre-Wagner, María Teresa. "La leyenda escandinava de Nelson Oxman en la narrativa moderna y posmoderna". Primer Congreso Internacional de Literatura. Medio siglo de literatura latinoamericana $1945-$ 1995, vol. 2. México: UAM, 1997. 